\title{
Predictors of Employee Preparedness for Retirement in Public Institutions within Mombasa County, Kenya
}

\author{
Kahuria Nelson Nyoro \\ PhD Student \\ Jomo Kenyatta University \\ nnnyoro@yahoo.com
}

\author{
Ogembo John Otieno \\ PhD Candidate \\ Kenyatta University \\ jogemboh@yahoo.com
}

\begin{abstract}
Life in retirement is a major concern for most countries, Kenya included particularly with regard to the quality of lives that the retirees live once out of employment. It is alleged that though a majority of employees live large while still in employment, there are a cadre of them whose lives take a drastic turn for the worse on leaving their jobs due to inadequate preparation for life in retirement. In Kenya, minimal empirical data exist to explain why this is so particularly for employees of public institutions. A descriptive survey study of 353 employees of public institutions in Mombasa County selected using both purposive and stratified random sampling responded to questionnaire items intended to gauge aspects of their preparation for life in retirement. The study assessed the extent to which employees' demographics (Bio data), membership to SACCOS, level of financial literacy and financial Life cycle predicted their preparedness for retirement. Data obtained was analysed descriptively using frequency, percentage, mean and standard deviation as well as inferentially using Chi - Square, Contingency Coefficient measure of association and regression analysis with the aid of statistical Package for Social Sciences (SPSS) version 20 computer software. Findings showed that employee work experience and monthly income as variables of their demographics are significant predictors of employee preparedness for retirement ( $p<0.05)$. Additionally, it was found that whereas employee work experience predicted their retirement preparedness negatively $(\beta=-.346)$, membership to a Sacco $(\beta=0.062)$, financial literacy $(\beta=0.097)$ and financial lifecycle $(\beta=0.057)$ are positive predictors. Further, the results showed that work experience, monthly income, SACCO membership, financial literacy and financial lifecycle are significant predictors $(p<0.05)$. It is therefore recommended that employers facilitate their employees to further their studies thus enable them enhance not only their literacy but also empower them to enjoy better terms of service which include better monthly salaries for an enhanced preparedness for retirement. Additionally, employers in conjunction with Sacco societies should organize more seminars on financial literacy and employee preparedness for retirement.
\end{abstract}

Keywords: Retirement, financial literacy, financial lifecycle.

\section{INTRODUCTION}

Retirement generally refers to the act of leaving a position of employment upon reaching a particular stipulated age or due to other specified reasons (Atchley, 1998). According to the researcher, it is one of the main transitions in life that symbolizes the individual leaving one part of a significant activity and entering into a new period in life. Usually, this transition often affects many life domains and is often accompanied by a decline in life satisfaction, self-evaluation, and quality of life (Lusardi \& Mitchell, 2011; Oyuke, 2009). Pinquart and Schindler, (2007) contends that retirement is frequently seen as an abrupt switch from being employed one minute to total ceasing of work activity in the next minute which is a more complex and progressive transition an assertion to which Wang (2007) agrees. Thus, having adequate coping skills for retirement could affect the outcome of this transition which implies that workers should adequately prepare. However, Oyuke (2009), maintains that despite the centrality and significance of retirement, preparation towards it by most workers it is often insufficient.

The main purpose of retirement preparation programs is to enable a worker form realistic perception of retired life and reduce anxiety about retirement. In other words, it aims at enhancing prospective retirees' adaptation to retirement and to provide assistance in managing this new phase in life, (Oyuke, 2009). Modigliani and Brumberg (1980) worked out a theory of spending based on the idea that people make intelligent choices about how much they want to spend at each age, limited only by the resources available over their lives. By building up and running down assets, working people can 
make provision for their retirement, and more generally, tailor their consumption patterns to their needs at different ages, independently of their incomes at each age. Employers will continue to play a vital role in helping workers save for retirement by offering retirement plans along with education and planning tools and retirement income options. Moreover, with so many workers planning to work longer, employers can offer opportunities to help older workers extend their working years and their transition into retirement. However, to help a worker to adequately prepare for retirement, the person may need to be excited about the prospects of retiring to become motivated enough to seek information and advice, and finally to take action to prepare for retirement. Otherwise it is possible for the fact that retirement is a reality in a worker's life to sink in when it is very late in the individual's working life, a trend that is unfortunately said to be apparent with many employees who retire from long years of service and continue to struggle with basic needs of life.

Employee preparedness for retirement has been shown to be dependent on a number of factors. These include environmental influences, individual differences, and psychological process factors (Engel, Blackwell, \& Miniard, 1990). According to the researchers, environmental influences include culture, social class, personal influence, family, and employment situation; individual differences are characterized by individual resources, motivation and involvement, knowledge, attitudes, personality, lifestyles, and demographics while psychological processes include information processing, learning, and attitude and/or behaviour change. Woerheide (2000) contends that work environment plays a key role in a person's decision to prepare for retirement particularly with regard to the type of qualified savings plan available at work. In general, research has shown that those who are employed in governmental agencies are more likely to have a defined benefit plan than other workers (Bureau of Labor Statistics, 2004), which may impact the employees' willingness to save privately for retirement. Similarly, Power and Hira (2004) found that professional employees are more likely than union members and clerical staff to have started planning for retirement. Roszkowski (1996) on his part reported that those employed in public-sector occupations have greater risk aversion than those employed in the private sector which is important because risk tolerance has been shown to be related to willingness to save and invest (Callan \& Johnson, 2002). This study attempted to assess the extent to which employee demographic factors, membership to a SACCO, financial literacy and financial lifecycle predicted their preparedness for retirement.

\section{Employee Demographics}

Relative to demographics, BMO retirement institute (2012) in a research report to test whether variables such as age, education, income, number of dependents, planned retirement age and years to retirement had an influence on involvement in financial preparation for Canadians showed that factors such as age and gender were not significantly related to financial preparedness for retirement scale (FPRS) when compared with other variables such as education, income and number of dependents. The findings showed that for men and women in same salary scale there was significant difference in their level of preparedness to retirement. The research further revealed that the FPRS score is best explained by years to retirement and education, which appear to be the two key drivers of retirement preparedness. However Pauline (2013) in her study found that; age, gender, marital status, parents' socio-economic status, availability of retirement information, monthly income, retirement planning and the availability of reliable social support systems significantly influenced retirement happiness. Two studies, Yuh et al. (1998a) and Yao et al. (2003), model observed that the likelihood that a household is adequately prepared for retirement is more dependent on financial variables as the driving forces and not as much the demographic variables.

\section{Membership to Financial Groupings}

Savings and Credit Cooperative societies (SACCOS) are voluntary associations or cooperative financial institution owned and controlled by their members and operated for the purposes of promoting saving, providing credit at low interest rates and providing other financial services to its members (Waweru 2011). Members regularly pool their savings, and subsequently may obtain loans which they may use for different purposes. Generally, the idea behind establishment of SACCOS is to promote savings and make credits available to the members. SACCOS are therefore important microfinancing institutions for mobilization of financial resources for various development activities. They are autonomous association of persons united voluntarily to meet their common economic, social, cultural needs and aspiration through a jointly owned, democratically controlled enterprise (RoK, 2008). As mentioned above, the sole objective of these societies involves mobilization of resources 
from which individual co-operators may benefit. Generally, co-operatives are organized into service and producer cooperatives (Branco, 2005). They are characterized by the intrinsic values and principles on which they are founded (Alila \& Obado 1990) and are based on the values of self-help, self-responsibility, democracy, equality, equity, and solidarity. The end product of these co-operatives is to attain the high living standards of its members. RBA (2010) carried out a research where a sample of employees drawn from the members of the different pension schemes across Kenya was interviewed. The results indicated that the pension scheme members have higher level of knowledge on pension scheme practices than general financial literacy issues and identify the lack of forum for involvement and lack of understanding of pension fund matters as the major hindrances to participation in pension scheme affairs, both of which can be addressed through appropriate finance and pension literacy programs. Keven (2012) alludes that to be a billionaire is not an easy thing, but women and men in Kimilili District have found an alternative way to conquer this dilema through self-help initiatives or groups commonly referred to as Chama's.

\section{Financial Literacy}

Worthington, (2005) indicates that financial literacy is the ability to make informed judgments and to take effective decisions regarding the use and management of money. Remund (2010) on the other hand defines it as a measure of understanding key financial concepts. In other words financial literacy refers to a situation in which an individual possess the knowledge sufficient to make informed decisions in regard to planning for retirement. The authors suggest that financially literate population is able to make informed decisions and take appropriate actions on matters affecting their financial wealth and well-being. Similarly Agnew, Szykman, Utkus, and Young (2007) maintain that financial knowledge enables individuals to build their financial skills and gives them confidence to undertake financial decisions for their pension schemes. Additionally, Gitari (2012) posited that knowledge on savings and plans to save is critical for effective long term financial decision making that is relevant to pension funds.

Retirement Confidence Survey conducted by Helman and Greenwald (2013) reports that only 23 percent of pre-retirees in South Africa who obtained advice on retirement planning which suggests that three out of four people might have little idea of how much to save for retirement. Without a savings goal a comfortable retirement is unlikely, even for the rich. This gives credence to a study by Duncan (2014) shows that South Africans don't save enough for retirement. According to a survey by Benchmark (2014), an annual review of the retirement industry, only 29 percent of South African retirees who are members of funds are able to maintain their standard of living when they retire; that falls to 10 percent when all retirement age South Africans are considered. And even that statistic obscures the true nature of South Africa's retirement landscape. OECD (2005), defines financial literacy as the combination of consumers and investors understanding of financial products and concepts and their ability and confidence to appreciate financial risks and opportunities, to make informed choices, to know where to go for help, and to take other effective actions to improve their financial well-being (Miller et al., 2009).

Onyango (2008) in his study observed that having knowledge of retirement issues is positively related to attitude toward retirement. Studies have found that those who believe that they know more about financial planning are more likely to have prepared for retirement. Garret et al (2003) while analyzing other studies concluded that training and intervention programs designed to boost financial knowledge should improve financial preparedness by triggering advanced planning activities. According to Taylor (1997) retirement education could improve employees' knowledge and behaviors related to retirement planning, and in turn, attitudes toward retirement and preparation for retirement. Bernheim and Garrett (2003) in their study investigated cross-sectional relationships between the availability of financial education provided by employers and savings. They found that employer-based financial education increased both saving in general and saving for retirement. Further, the study found that brief training programs stimulated individual's saving behaviors and decision-making competencies.

Clark and d'Ambrosio (2003) investigated the effects of one-hour retirement seminars on retirement attitudes and behaviors. They found that participation in seminars changed individual's retirement goals and retirement savings behaviors in a positive way. Similarly, Taylor-Carter et al (1997) found that informal financial planning had a positive effect on anticipated financial expectation and that formal retirement education seminars which included financial management had positive effects on 
anticipated retirement satisfaction. According to Chan and Stevens (2008) households base pension and retirement saving decisions upon limited and sometimes incorrect pension knowledge. One may argue whether financial literacy affects knowledge of pensions and Social Security benefits. A study by Gustman, Steinmeier and Tabatabai (2010) indicates that there is no any direct relationship between basic cognitive skills (numeracy) and knowledge of retirement plan characteristics and Social Security. While there is a positive relationship between pension wealth and knowledge. The study argues that the causality is more likely to run from pension wealth to pension knowledge than the other way around, and that the positive numeracy-wealth relationship should not be taken as evidence that increasing cognitive skills and numeracy will increase the wealth of households as they enter into retirement.

\section{Financial Lifecycle}

The Study by BMO institute (2012) illustrated that time remaining to retirement, and not age, is a key indicator of an individual's financial preparedness for retirement. The Study indicates that young adults under the age of 35 are the least prepared, based on an analysis that considered attitudes and behaviour as key measurements for financial preparedness for retirement. These findings can be helpful to the younger generations as common wisdom states that the earlier people start to save for retirement, the greater the potential that they will achieve future financial security. Tina (2012) in her study observed that the closer people are to their target retirement date, the more likely they are to be prepared for retirement. However, findings indicate that the key indicator is the time remaining to retirement, not the actual age of the individual. For example, in certain cases, it may be possible for a younger person to actually have less time before his or her desired retirement age than an older person (i.e., a 40-year-old who desires to retire at the age of 50, and therefore has ten years left before retirement, compared with a 50-year-old who aims to retire at the age of 65 , and therefore has 15 years left).

Nevertheless, as expected, the research based on attitudes and behaviour concluded that the youngest generation of adults is the least prepared for retirement, because in all probability, their retirement date is the furthest away. Interestingly, the Study findings suggest that young adults under the age of 35 may be overly optimistic, since as many as 41 per cent expect to retire early (i.e. before age 60) In addition to the time remaining until the target retirement date, the Research revealed that a person's level of education was another indicator of financial preparedness for retirement It was found that higher levels of education can greatly influence people's motivation and involvement in taking a more active role in planning their retirement by, for example, attending seminars or consulting financial planners, which are behaviours that increase basic financial education and empower people to make sound financial decisions and take action accordingly. This is why improving the financial literacy of all Canadians is so important, and it may also explain why government and financial institutions have taken an active role in advocating the promotion of financial literacy through diverse national campaigns and initiatives.

According to Tina (2012) in her study indicates that young adults under the age of 35 are the least prepared, based on an analysis that considered attitudes and behaviours as key measurements for financial preparedness for retirement. These findings can be helpful to the younger generations as common wisdom states that the earlier people start to save for retirement, the greater the potential that they will achieve future financial security. Strengthening efforts at improving their financial education can go a long way to modifying attitudes and behaviours so that their level of involvement may increase sufficiently to drive positive information-seeking behaviour and lead them to take action. Onyango (2008) observed that quite often, the elderly people were not necessarily poor when younger. Old age poverty comes about because, safe and reliable long term savings are rare and they rarely provide opportunities to convert lump sum savings into annuities or other instruments which provide a stream of payments throughout one's retirement.

According to a study by BMO Institute (2012), to help adequately prepare for retirement, a person may need to be excited about the prospects of retiring to become motivated to seek information and advice, and finally to take action to save for retirement. The stronger the attitudes and behaviours are before taking the actual step of saving in retirement accounts, the greater the likelihood that the chosen financial action will help ensure a comfortable future retirement. This means that attitudes and behaviours can be strong predictors of financial preparedness for retirement, and the earlier these can be shaped, the better prepared a person can be for retirement. Carroll (1997), In his study, 
precautionary saving, has shown that people with uncertain future earnings who are sufficiently prudent will never borrow, if there is the possibility, however remote, that they will not earn enough to be able to repay their debts. If such people expect their earnings to grow over time, they will nevertheless keep their consumption within their current incomes, thus inducing a close articulation, or "tracking," between consumption and income. In this case, although people are maximizing their expected life time utility, as postulated by the life-cycle theory under uncertainty, their consumption is effectively constrained by their current incomes. Such behavior is directly contrary to one of the central insights of the Modigliani model, that the profile of consumption can be detached from the profile of income, and much more like the pre-Modigliani and Keynesian accounts of saving.

\section{OBJECTIVES OF THE STUDY}

The overall objective of this study was to determine the extent to which various factors predict employee preparedness for retirement. Specifically, the study sought:

- To determine the extent to which employee demographics predict their preparedness for retirement.

- To establish the extent to which membership of an employee to a savings and credit society predict their preparedness for retirement.

- To determine the extent to which employees' financial literacy predicts their preparedness for retirement.

- To establish the extent to which an employees' financial lifecycle predict their preparedness for retirement.

\section{CONCEPTUAL FramewORK}

Figure .1 conceptualizes the relationship between the elements identified as important in the employee preparedness for retirement.

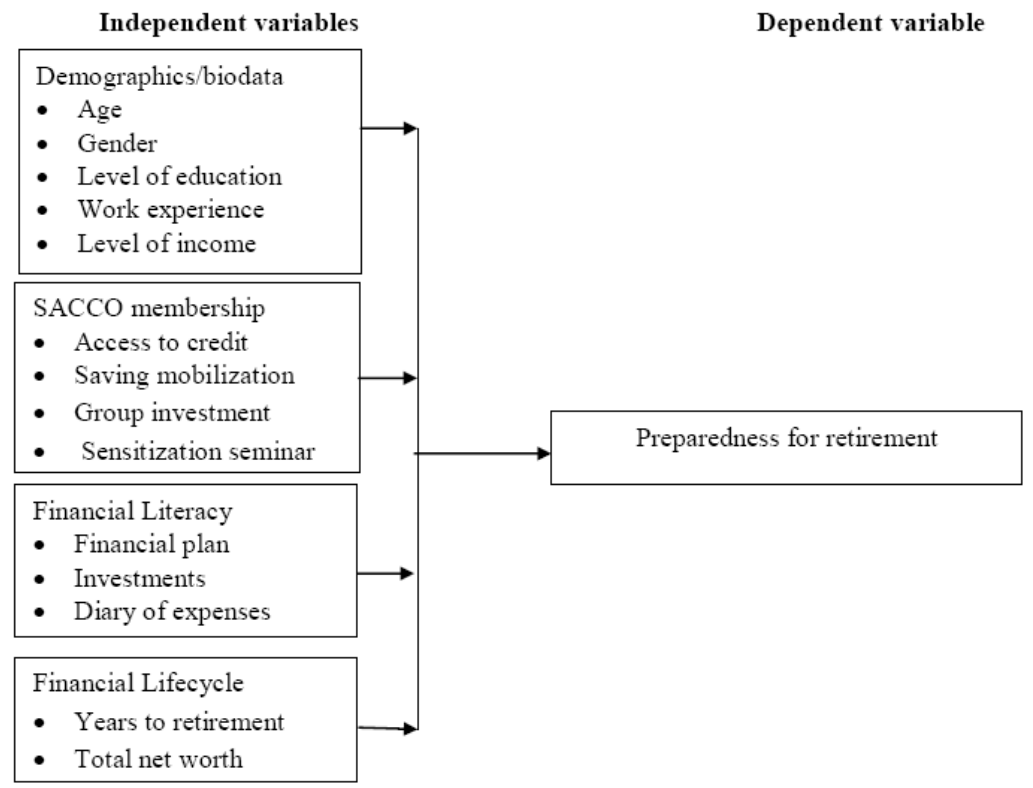

Fig1. Hypothesized interaction of elements predicting employee preparedness for retirement

An employee preparation for retirement involves a number of factors conceived as the independent variables in this study. The variables include employees' demographics such as age, gender, level of education, work experience and level of income as well as membership to a financial grouping such as Sacco, financial literacy and financial lifecycle. Researchers have maintained that employees with very little income have difficulty balancing consumption and savings implying that employers need to look at their pay structure to support employees ability to spare some money for retire. However it is possible for people earning the same amount of money to prepare differently for retirement because of their lifestyles (Consumption Habits). Similarly the number of dependents one has influences the consumption level and thus the amount saved for retirement. While preparation for retirement is seen 
by many as a personal matter scholars agree that investment groups and chamas help their members to plan for retirement. Chamas and investment groups provide avenues for saving, investing and provide financial information. Financial literacy is the variable considered most significant in supporting one to prepare for retirement. In fact financial literacy is rated higher than the socio demographic factors as observed by many scholars. Similarly, financial lifecycle has been considered by scholars as a factor stronger than age. It has been argued that the closer one is to retirement the more prepared they are to retire stronger than their age. That basically means a person planning to retire young would prepare for retirement more than their age mate or even older people who want to stay longer in employment.

\section{RESEARCH METHODOLOGY}

\subsection{Participants and Procedure}

Participants were 353 (234 or $66.3 \%$ males and 119 or $33.7 \%$ females)employees of public institutions within Mombasa county, Kenya. Respondents were told that the study aimed at assessing factors predicting their preparedness for retirement. They completed a questionnaire constructed by the researchers.

\subsection{Measures}

Employee Demographic Variables. Five demographic factors were considered for the study based on the preliminary analysis carried. These included their age, gender as well as level of education. Other factors considered were work experience and monthly income.

Membership to a Sacco. Five statements were used to assess the extent to which an employee membership to a Sacco impacted their preparedness for retirement; all ratings were made on a 5-point scale $(1=$ strongly disagree, $5=$ strongly agree $)$. A mean score of each item was computed.

Financial literacy. Five statements were used to assess the extent to which an employee financial literacy influenced their preparedness for retirement; all ratings were made on a 5-point scale $(1=$ strongly disagree, $5=$ strongly agree). A mean score of each item was computed.

Financial lifecycle. Seven statements were used to determine the extent to which an employee financial lifecycle predicted their preparedness for retirement; all ratings were made on a 5-point scale ( $1=$ strongly disagree, $5=$ strongly agree). A mean score of each item was computed.

Dependent Variable. Employee retirement preparedness was measured based on the respondents' conception of a set of five statements.

\section{RESUlTS AND DISCUSSION}

\subsection{Descriptives}

Means, standard deviations, and intercorrelations for scores on each of the variables are presented in Table 1 for the total sample (Appendix) while results from regression analysis are presented in Table 2. Preparedness for retirement was positively and significantly correlated with work experience, membership to a Sacco, financial literacy and financial lifecycle. It was also highly though negatively correlated with employees' level of education. Respondents' financial literacy was strongly correlated with age, gender, level of education level of income income and membership to a Sacco while financial lifecycle was strongly correlated with age, Sacco membership and financial literacy. As was expected, Sacco membership was strongly correlated with age, gender, level of education and level of income. The implication is that membership to a Sacco, financial literacy and financial lifecycle are mutually exclusive. Further exploratory $\mathrm{Chi}$ - square analysis showed that at .05 level of significance, employees' age, level of education and income had a significant influence on their preparedness for retirement, $\mathrm{X}^{2}=24.915 ; \mathrm{df}=3 ; \mathrm{P}=.003 ; \mathrm{X}^{2}=42.259 ; \mathrm{df}=4 ; \mathrm{P}=.000$ and $\mathrm{X}^{2}=42.193 ; \mathrm{df}=3 ; \mathrm{P}=.000$ respectively. Contingency coefficient measure of association indicated that $25.7 \%$ of the variation in preparedness for retirement could be attributed to the employees' age, $32.7 \%$ to their level of education as well as monthly income with a similar margin.

\subsection{Demographics and Employee Preparedness for Retirement}

The first objective intended to determine the extent to which respondents' demographic characteristics predicted their preparedness for retirement. Respondents demographic variables considered for review include age, gender, academic qualification, work experience and monthly income. Frequency and 
percentage were used to illustrate its descriptive effect while regression analysis was used to infer on the existing relationship. Data obtained illustrated that the respondents included $234(66.3 \%)$ males and $119(33.7 \%)$ females; $96(27.2 \%)$ were aged below 30 years, $147(41.6 \%)$ were 30 to 40 years, 78 $(22.1 \%)$ were 41 to 50 years while the remaining $32(9.1 \%)$ were found to be over 50 years. Relative to academic qualification, 35 (9.9\%) were primary school leavers, $114(32.3 \%)$ had secondary school certificate, $66(18.7 \%)$ were diploma certificate holders, $111(31.4 \%)$ were graduates while $27(7.6 \%)$ had postgraduate qualifications. In terms of work experience, $71(20.1 \%)$ worked for less than 5 years, $135(38.2 \%)$ for between 5 and 10 years, $71(20.1 \%)$ for between 11 and 20 years and $76(21.5 \%)$ for more than 20 years. Lastly, it was found that 76 (21.5\%) of the respondents earned less than KSh. 25,000; 132 (37.4\%) earned between KSh. 25,000 and 50,000; 94 (26.6\%) earned between KSh. 50,001 and 100,000 and the remaining $51(14.4 \%)$ earned more than KSh. 100,000.

The hierarchical regression model used showed that employee demographics accounted for $13.0 \%$ of the total variance on employee preparedness for retirement $F(5,353)=10.389, \mathrm{p}<.001$. The model which was found to be significant showed that $0.8 \%$ of the variance in preparedness to retire was accounted for by an employee's age alone, $F(1,333)=1.570, \mathrm{p}=.117$. When entered, gender accounted for $0.1 \%$ of variance in preparedness to retire beyond that accounted for by age $F(2,332)$ $=-.483, \mathrm{p}=.629$. Level of education, work experience and monthly income explained $0.3 \%, 8.3 \%$ and $3.6 \%$ of total variance in preparedness to retire respectively $F(3,331)=.1 .091, \mathrm{p}=.276 ; F(4,330)=-$ $6.006, \mathrm{p}<.001$ and $F(5,329)=3.748, \mathrm{p}<.001$.Specifically, age and level of education were found to have an insignificant positive influence on employee preparedness to retire, gender was found to have a negative insignificant influence while for experience, the influence was significant though negative. Additionally, the analysis illustrated that an employee monthly income had a positive significant influence. It could therefore be concluded that among the demographic variables, an employee's age gender and level of education are insignificant predictors of their preparedness to retire with that of age and level of education being positive. At the same time it can be adduced that work experience and an employee's monthly income are significant predictors with that of income being positive. These findings were found to generally support those ofPauline (2013) who in her study found that; age, gender, marital status, parents' socio-economic status, availability of retirement information, monthly income, retirement planning and the availability of reliable social support systems significantly influenced retirement happiness. Two studies, Yuh et al. (1998a) and Yao et al. (2003), model observed that the likelihood that a household is adequately prepared for retirement is more dependent on financial variables as the driving forces and not as much the demographic variables. Likewise, BMO retirement institute (2012) showed that for men and women in same salary scale there was significant difference in their level of preparedness to retirement. The research further revealed that the FPRS score is best explained by years to retirement and education, which appear to be the two key drivers of retirement preparedness.

\subsection{Sacco Membership and Retirement Preparedness}

The second aim of the study was to determine the influence of an employee membership to a Sacco on their preparedness for retirement. The findings show that a majority of respondents were of the opinion that their membership to Sacco society influenced their preparedness for retirement giving the factor an overall mean rating of 3.44 out of 5 and a standard deviation of 1.26. In particular, a majority indicated that they had secured assets through the help of their Saccoin anticipation of retirement giving the element the highest mean ranking of 3.90 and a standard deviation of 1.11. Similarly, a majority of the respondents maintained that their membership of a Sacco had enabled them to save for the future thus giving the element a modest mean rating of 3.87 and standard deviation of 1.31 and a considerable proportion confessing that affordable credit from their Sacco had enabled them to invest for the future giving the element a mean of 3.86and standard deviation of 1.17. Lastly, slightly more than half of the respondents indicated thattheir Sacco organizes seminars on financial literacy $(\mathrm{M}=2.29, \mathrm{SD}=1.44)$ with slightly fewer maintaining that theirSacco organizes seminars on preparation for retirement $(\mathrm{M}=2.65, \mathrm{SD}=1.27)$. Regression analysis showed that belonging to a Sacco has a significant positive influence on retirement preparedness $(\beta=0.062)$ and that on the whole it accounted for $9.1 \%$ of the total variance $F(6,328)=6.241, \mathrm{p}<.001$. The results imply that a significant proportion of the respondents believe that membership to a Sacco predicts positively an employee preparedness for retirement. This agrees with the assertions of Alila and Obado (1990) who maintain that Saccos are based on the values of self-help, self-responsibility, 
democracy, equality, equity, and solidarity and that the end product of these co-operatives is to attain the high living standards of its members. Similarly, RoK (2008) insists that SACCOS are important micro-financing institutions for mobilization of financial resources for various development activities. They are autonomous association of persons united voluntarily to meet their common economic, social, cultural needs and aspiration through a jointly owned, democratically controlled enterprise.

\subsection{Financial Literacy and Employee Preparedness for Retirement}

The study also aimed at determining the influence of employee financial literacy on their retirement preparedness. The results show that most of the respondents confessed that financial literacy has helped them diversify their investments thussecuring their future giving the element the highest mean of 3.79 and a standard deviation of 1.12 which shows the extent of effect of financial literacy. Similarly, the findings show that a majority of the respondents were following awell prepared financial plan( $\mathrm{M}=3.63, \mathrm{SD}=1.08)$, many acknowledged that financial literacy has helped them save for emergencies than borrow $(\mathrm{M}=3.60, \mathrm{SD}=1.14)$, some insisted that financial literacy has enabled them to take an insurance policy which was adequate for them and their dependants $(M=3.31$, $\mathrm{SD}=1.23$ ) while others maintained that their employer prepares seminars on retirement planning $(\mathrm{M}=3.15, \mathrm{SD}=1.40)$. This means that a majority of the respondents felt that they had acquired adequate financial skills which they were confident could enable them not only invest for the future but also face retirement confidently. The factor thus received an overall mean rating of 3.50 and a standard deviation of 1.19. Regression analysis showed that financial literacy has a significant positive influence on employee preparedness for retirement $(\beta=0.097, \mathrm{p}<.001)$ and accounted for $12.1 \%, F(7,327)=3.618, \mathrm{p}<.001$ of the total variance in preparedness for retirement. The finding is in supports of previous findings. According to Remund (2010), financially literate population are able to make informed decisions and take appropriate actions on matters affecting their financial wealth and well-being. Similarly, Agnew, Szykman, Utkus, and Young, (2007) in their study found that financial knowledge enables individuals to build their financial skills and gives them confidence to undertake financial decisions for their pension schemes an aspect also supported by Gitari (2012).

\subsection{Financial Lifecycle and Employee Preparedness for Retirement}

Lastly the study set out to determine the extent to which financial lifecycle influenced an employee preparedness for retirement. Results indicate that a majority of respondents maintained that they have a separate retirement plan different from the one maintained by their employer thus the highest mean rating of 3.23 and standard deviation of 1.25. Likewise, a large proportion acknowledged that they operate a personal business $(\mathrm{M}=3.20, \mathrm{SD}=1.26)$, some were categorical that theirincome in retirement would be at least $60 \%$ of their current income $(\mathrm{M}=3.18, \mathrm{SD}=1.16)$ and that they have enough information on the value of their pension and know how to compute it(M=2.99, $S D=1.25)$. The prospect of having a separate pension scheme and of operating a personal business by a majority of the respondents illustrates high level of preparedness for retirement that a majority of the respondents have attained due to the effect of their financial lifecycle. Further, a slight majority indicated that they would retire before the time stipulated for retirement $(\mathrm{M}=2.8768, \mathrm{SD}=1.16)$, some averred thatthey have saved enough money for their dependants $(\mathrm{M}=2.7867, \mathrm{SD}=1.17)$ and that they had finished their retirement home $(\mathrm{M}=2.76, \mathrm{SD}=1.15)$. The factor therefore attained a mean ranking of 3.00 and standard deviation of 1.20 implying that a majority of the respondents are of the opinion that financial lifecycle influences preparedness for retirement.Regression analysis showed that financial lifecycle has a significant positive influence on an employee preparedness for retirement $(\beta=0.057, p<.001)$ and accounted for $11.9 \%$ of the total variance, $F(8,326)=8.265, \mathrm{p}<.001$. This implies that a significant proportion of the respondents felt that an employee financial lifecycle predicts their preparedness for retirement. Tina (2012) in her study observed that the closer people are to their target retirement date, the more likely they are to be prepared for retirement. However, the Research indicates that the key indicator is the time remaining to retirement, not the actual age of the individual. A study by BMO institute (2012) specifically illustrated that the time remaining to retirement, and not age, is a key indicator of an individual's financial preparedness for retirement.

\section{IMPLICATIONS, LIMITATIONS AND CONCLUSIONS}

\subsection{Implications}

According to our findings, employee preparedness for retirement is predicted by a retinue of factors including employee demographic factors such as work experience and monthly income, membership 
to financial groupings such as Sacco, financial literacy and financial lifecycle. This implies that employers should not only consider putting in place mechanisms of remunerating their employees well but also avenues of enhancing employees financial literacy as well as their involvement with financial groupings. This would enable employeesnot only to acquire investment skills but also empower them by being able to save and access financial services thus adequately prepare for retirement.

\subsection{Limitations and Directions for Further Research}

It should be noted that this study has a number of limitations. The quantitative research methodology adopted was mainly based on self-report measures. Future studies could build on these. Longitudinal studies are particularly more appropriate since they may be helpful to track changes in thinking processes and related financial management and investment related issues. It should also be noted that the findings of the present study have to be interpreted in a careful way since a convenience sampling procedure was applied. Respondents were drawn from public institutions that the researchers could readily access which could have caused uncontrolled bias.

\subsection{Conclusion}

Our study has provided insight on predictors of employee preparedness for retirement, a Kenyan context. The findings suggest that employee level of income, membership to financial groupings such as Sacco, financial literacy and financial lifecycle are the main positive predictors of their preparedness for retirement. The results provide an avenue with which employees can be empowered to better prepare for life in retirement.

\section{REFERENCES}

Agnew, J., \& J. Young, (2007) Literacy, Trust and 401(k) Savings Behavior. Boston; Center for Retirement Research.

Alila, P.\& Obado, P. (1990):Co-operative credit: The Kenyan SACCOS in a historical and development perspective; Working paper.

Atchley, R. C. (1998). Educating the public about personal finance: A call for action. Journal of the American Society of CLU \& ChFC, (28), pp 30-32

Bernheim, B. D., \& Garrett, D. M. (2003). The effects of financial education in the workplace: evidence from a survey of households. Journal of Public Economics, 87(7), 1487-1519.

Callan, V. J., \& Johnson, M. (2002). Some guidelines for financial planners in measuring and advising clients about their levels of risk tolerance. Journal of Personal Finance, 1(1), 31-44.

Chan, S., \& Stevens, A. H. (2008). What you don't know can't help you: Pension knowledge and retirement decision-making. The Review of Economics and Statistics, 90(2), 253-266.

Clark, R. L., \& d'Ambrosio, M. (2003). Financial education and retirement savings. Available at SSRN 390642.

Engel, J. F., Blackwell, R. D., \& Miniard, P. W. (1990). Customer behavior.

Helman, R. \&Greenwald, M\& Associates. "The 2013 Retirement Confidence Survey: Perceived Savings Needs Outpace Reality for Many," Issue Brief , No. 384, EBRI, March 2013, available at www.ebri.org/ publications/ib/?fa=ibDisp\&content_id=5175.

Lusardi, A. \& Mitchell, O.(2011). How ordinary consumers make complex economic decisions: Financial literacy and retirement readiness, NBER Working Paper, 15350

Oyuke, J. (2009). New Retirement Age Limit Faces Big Hurdles. Nairobi: The Standard.

Pinquart, M., \& Schindler, I. (2007). Changes of life satisfaction in the transition to retirement: a latent-class approach. Psychology and aging, 22(3), 442.

Power, M. L., \& Hira, T. K. (2004). University-Provided Retirement Planning Support and Retiree Financial Satisfaction During Retirement: Differences by Gender, Job Classification, and Planning Behavior. Risk Management and Insurance Review, 7(2), 121-149.

Remund, D. L. (2010). Financial literacy explicated: The case for a clearer definition in an increasingly complex economy. Journal of Consumer Affairs, 44(2), 276-295. 
Roszkowski, M. J. (1998). Risk to lerance in financial decisions. In D. M. Cordell (ed.), Readings in Financial Planning (pp. 281-328). Bryn Mawr, PA: The American College.

Waweru, M. A. (2011). Comparative analysis of competitive strategy implementation. Journal of management and strategy, 2(3), p49.

\section{Appendix: Result Tables}

Table1. Means, standard deviations, and correlations between the variables of the study $(N=353)$

\begin{tabular}{|c|c|c|c|c|c|c|c|c|c|c|c|}
\hline Variables & Mean & SD & 1 & 2 & 3 & 4 & 5 & 6 & 7 & 8 & 9 \\
\hline 1. Age & 2.13 & .917 & - & -.069 & $.119^{*}$ & $.722 * *$ & $.358 * *$ & $.271 * *$ & $.288 * *$ & $.180 * *$ & .087 \\
\hline 2.Gender & - & - & - & - & .054 & $.114^{*}$ & -.003 & $-.151 * *$ & $-.231 * *$ & .058 & -.035 \\
\hline 3. Education & 2.95 & 1.16 & & & - & $.151 * *$ & $.276^{* *}$ & $.136^{*}$ & $.120 *$ & -.026. & .060 \\
\hline 4. Experience & 2.43 & 1.04 & & & & - & $.445 * *$ & -.041 & -.006 & $-.016-$ & $-.133 *$ \\
\hline 5. Monthly income & 2.34 & .973 & & & & & - & $.188 * *$ & $.182 * *$ & -.026 . & $.134 *$ \\
\hline 6. Sacco membership & p 17.21 & 4.73 & & & & & & - & $.726^{* *}$ & $.123 *$ & $436^{* *}$ \\
\hline 7. Financial literacy & 17.47 & 4.53 & & & & & & & - & $.326 * *$ & $* 547 * *$ \\
\hline 8. Financial lifecycle & 21.01 & 5.85 & & & & & & & & - & $506 * *$ \\
\hline
\end{tabular}

Table2. Regression Analysis of Predictors of Employee Preparedness for Retirement

\begin{tabular}{|lllcccrc|}
\hline Variables & \multicolumn{1}{c}{$\mathrm{B}$} & \multicolumn{1}{c}{$\mathrm{p}$} & $\mathrm{t}$ & $\mathrm{p}$ & $\mathrm{R}^{2}$ & Adj. $^{2}$ & $\mathrm{R}^{2}$ change \\
\hline Age & .079 & .086 & 1.570 & .117 & .007 & .004 & .007 \\
Gender & -.051 & -.026 & -.483 & .629 & .008 & .002 & .001 \\
Education & .038 & .061 & 1.091 & .276 & .012 & .003 & .004 \\
Experience & -.346 & -.469 & -6.009 & .000 & .109 & .098 & .097 \\
Income & .188 & .2193 & .748 & .000 & .145 & .132 & .036 \\
Sacco membership & .062 & .353 & 6.241 & .000 & .236 & .222 & .091 \\
Financial literacy & .097 & .526 & 7.847 & .000 & .357 & .343 & .121 \\
Financial lifecycle & .057 & .388 & 8.625 & .000 & .477 & .464 & .119 \\
\hline
\end{tabular}

\section{AUTHORS' BIOGRAPHY}
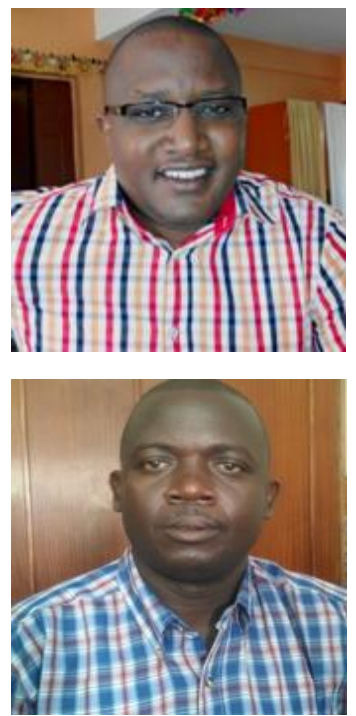

Mr Nelson Nyoro is the Mombasa County Cooperative Officer and a lecturer at the Co-operative University of Kenya. $\mathrm{He}$ is a $\mathrm{PhD}$ in Business Administration student at the Jomo Kenyatta University of Agriculture and Technology and also holds an MBA (Finance) and BBA (Accounting and Finance) from the Kenya Methodist University.

Mr John Ogembo is an experienced educationist with over 15 years teaching experience both at secondary and tertiary levels. He is currently a lecturer at the South Eastern Kenya University (SEKU). A PhD candidate at Kenyatta University, Mr. Ogembo also holds a Master of Education (Educ. Tech) and a B Ed. (Sc) from the same university. 